\title{
Interpretasi, Ekspresi, dan Style Film Pendek Perspektif Terbalik karya Andree Sascha
}

\author{
Yunis Dwi Retnania, 1 , \\ a Universitas Airlangga, Jalan Dharmawangsa Dalam Selatan, Surabaya, Indonesia, 60286 \\ ${ }^{1}$ yunisretnani@gmail.com*
}

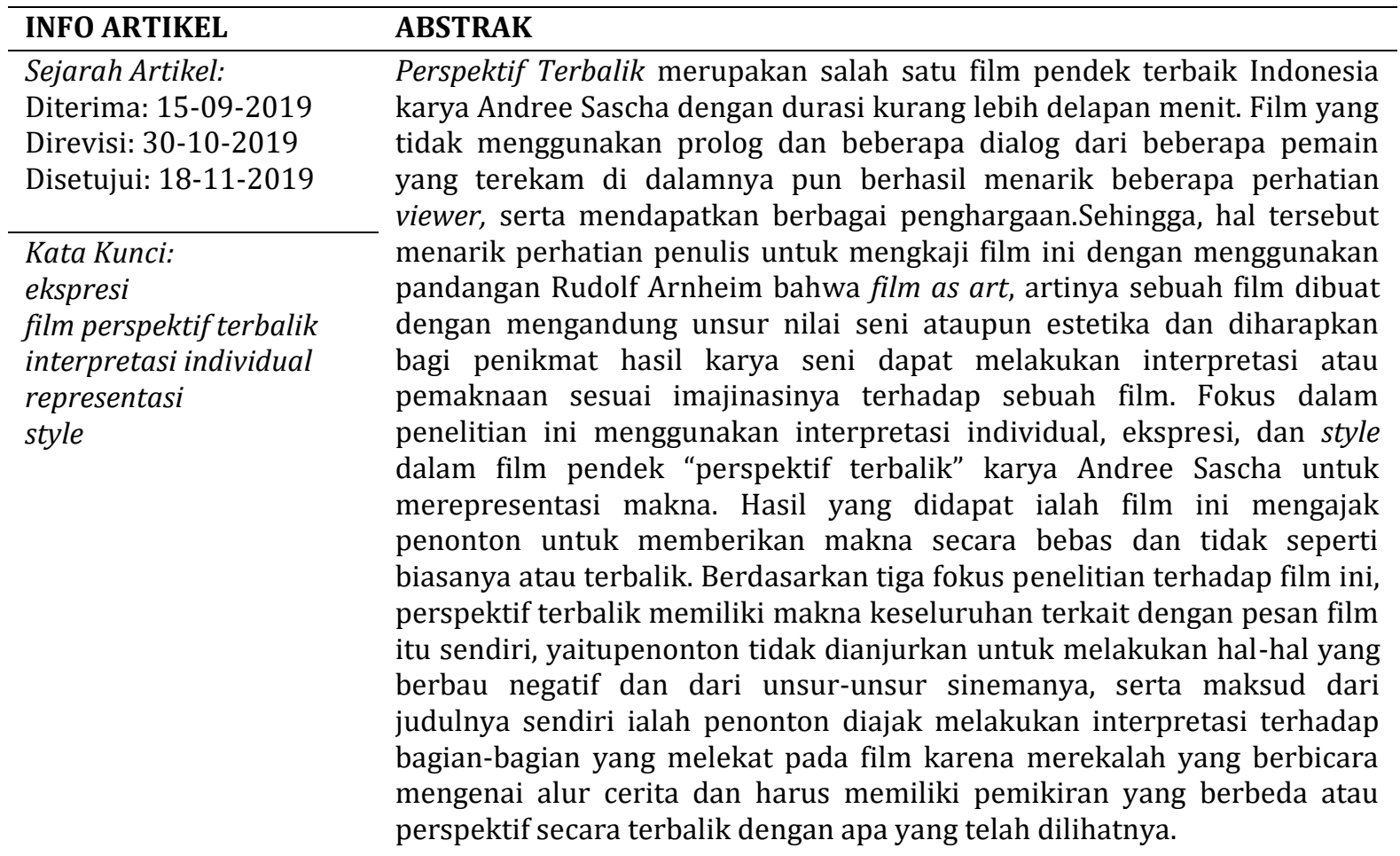

\begin{tabular}{|c|c|}
\hline & ABSTRACT \\
\hline $\begin{array}{l}\text { Keywords: } \\
\text { expression } \\
\text { the reversed perspective } \\
\text { film } \\
\text { individual interpretation } \\
\text { representation } \\
\text { style }\end{array}$ & $\begin{array}{l}\text { Perspektif Terbalik was one of the best Indonesian short films with the } \\
\text { duration of approximately eight minutes. The film, not having any } \\
\text { prologue and contains only several dialogues by the actors, managed to } \\
\text { attract wide attention and achieved prestigious awards. Therefore, it } \\
\text { concerned the writer to examine the film using Rudolf Arnheim's } \\
\text { perspective of film as art, meaning that a film can be made with artistic or } \\
\text { esthetical values and it is hoped that the audience will be able to interpret } \\
\text { and comprehend the imagination of the film. The focus of the study uses } \\
\text { individual interpretation, expression and style found in the "The Reversed } \\
\text { Perspective" short film to find the meaning of representation. The result of } \\
\text { the study shows that the film challenges the viewers to interpret freely and } \\
\text { in reverse. Based on the three focuses toward the film, the audience are } \\
\text { not encouraged to do negative things and from its cinematic aspects as } \\
\text { well as the title of the film itself, it means that viewers are stimulated to } \\
\text { create an interpretation toward certain parts that cling to the film because } \\
\text { they are the ones who talk about the plot and have to possess different } \\
\text { ways of thinking or perspectives that reverse what they have seen. }\end{array}$ \\
\hline
\end{tabular}




\section{PENDAHULUAN}

Film dinilai sebagai karya seni menurut pandangan Rudolf Arnheim ialah sebuah film harus menyajikan bentuk visualisasi atau gambaran secara fokus dan baik sehingga menampilkan karakteristik yang kuat dari sebuah gambar tersebut ketika diproduksi. Hal inilah yang menjadi dasar utama pemahaman Arnheim terkait film as art, dimana penikmat film diharapkan dapat memberikanimajinasi atau interpretasi yang menghasilkan sebuah pemaknaan terhadap film yang ditonton melalui komposisikomposisi yang melekat dalam objek gambaran film yang kemudian direpresentasikan sesuai keinginan penikmat film tersebut. Selain untuk dinikmati, hasil karya seni juga harus mampu mengajak penikmatnya untuk merasakan bentuk estetika ataupun sebuah pesan yang terkandung didalamnya meskipun berbeda dari tujuan dan maksud pembuat film.

Industri film saat ini tidak lagi menganggap film sebagai sebuah karya seni, tetapi mereka hanya mencari keuntungan, kemudian menggunakan film sebagai komersil untuk menarik perhatian beberapa sponsor, baik dari sponsor perusahaan ataupun Production House. Sehingga, dengan adanya alasan yang seperti itu mereka tidak lagi memperhatikan unsurunsur seni atau estetika film yang seharusnya melekat di dalamnya. Para industri film sekarang justru menghilangkannya dan menggantinya dengan peran penting dialog sebagai pemahaman alur cerita yang ingin disampaikan ataupun menggunakan stars (artis) papan atas yang sudah mempunyai nama di dalam dunia hiburan, sebagai upaya agar filmnya laku keras dipasaran.

Rudolf Arnheim dalam film as art menentang hadirnya dialog yang dilakukan oleh pemain film atau suara-suara yang dimunculkan sebagai pelengkap film karena dianggap dapat merusak nilai artistik sebuah film. Film yang mengandung suara tersebut biasa disebut dengan film talkies, sebuah film yang sedang berkembang pada industri perfilman di masa sekarang karena lebih menarik daripada film yang hanya menampilkan gambar. Namun sebenarnya film yang hanya menampilkan komposisikomposisi atau gambar-gambar yang memiliki satu kesatuan cerita inilah yang mempunyai nilai seni, sebab objek utama dari film ialah gambar yang bergerak. Bagi Arnheim, memasukkan unsur suara bukan merupakan kesalahan yang fatal dalam sebuah film, hanya saja unsur suara ini tidak mengambil alih porsi gambar sebagai objek utama.

Oleh karena itu, untuk memudahkan pemahaman terhadap film as art-Rudolf Arnheim ini, penulis akan melakukan sebuah penelitian untuk merepresentasikan makna dalam film pendek yang berjudul "Perspektif Terbalik" dengan menggunakan interpretasi individual, ekspresi dan komunikasi, dan bentuk atau style sebagai fokus penelitian film tersebut.

\section{METODE}

Penelitian ini menggunakan metode kualitatif agar hasil yang ingin disampaikan oleh penulis berdasarkan apa adanya tanpa dibuat-buat. Di dalam tahap metode ini, penulis juga akan menggunakan tiga fokus penelitian sebagai berikut.

1. Interpretasi Individual adalah penulis melakukan penafsiran terhadap objek penelitian sesuai dengan pandangan penulis. Selain itu, peneliti dapat bertindak sebagai interpretan seni visual, sekaligus menginterpretasikan produksi dan pembuat seni dan desain visual (Ida, 2014). Dalam hal ini, penulis akan melakukan interpretasi pada setiap komposisi-komposisi yang melekat dalam film pendek tersebut.

2. Ekspresi dan komunikasi, artinya pada penelitian ini penulis ingin melihat bentuk ekspresi yang digambarkan oleh produksi film, agar mudah menangkap pesan yang ingin dikomunikasikan atau disampaikan. Kajian budaya visual untuk melihat apa pesan yang coba diekspresikan, dan dikomunikasikan 
oleh hasil desain visual (Ida, 2014). Selain melakukan interpretasi pada tiap komposisi yang membentuk satuan gambar, penulis juga akan melihat pesan yang ingin diekepresikan dan dikomunikasikan oleh pembuat film pendek tersebut.

3. Bentuk/format dan Style adalah unsurunsur karakteristik yang termuat dalam desain visual atau gambar. Penelitian ini lebih dikenal dengan penelitian 'Stylistic' karena lebih fokus pada grafis dan karakteristik style objek visual seperti: warna, garis, bentuk, tekstur, dan tata letak serta komposisinya (Ida, 2014). Fokus yang terakhir ini digunakan penulis untuk memahami struktur-struktur gambar agar memperoleh pemaknaan secara jelas.

Ketiga fokus tersebut digunakan oleh penulis dalam mengamati film pendek "perspektif terbalik" karena saling berkaitan dan memberikan batasan pada pemaknaan film agar tidak melebar diluar penelitian, selain objek gambar yang termuat dalam film.

Penelitian ini juga menggunakan pandangan site of self. Terdapat tiga area dalam melakukan penelitian visual, menurut (Gillian Rose dalam Ida, 2014) mengatakan bahwa "tiga area ini menggambarkan sudut pandang mana yang diambil oleh peneliti ketika melakukan penelitian objek visual yang sedang diamatinya, antara lain: Site of self, site of production, and site of audience." Pandangan site of self merupakan pandangan terhadap wilayah penulis sendiri, penulis bebas dalam menginterpretasi ataupun mengkritisi objek visual untuk menghasilkan pemaknaan sesuai dengan pemahaman penulis. Pandangan ini tentu saja dilakukan bersamaan dengan menggunakan tiga fokus penelitian yang telah dijelaskan sebelumnya. Hal ini dilakukan karena menurut penulis ketiga fokus dan pandangan seperti ini membentuk satu kesatuan yang tidak dapat dipisahkan.

\section{HASIL DAN PEMBAHASAN}

Film pendek dengan judul Perspektif Terbalik rilis pada tahun 2014 dengan durasi kurang lebih delapan menit. Film yang disutradarai oleh Andree Sascha ini mampu meraih beberapa penghargaan, salah satunya ialah best movies on HELLOFEST 10 2014 seperti yang tertulis dalam web resmi filmpendek.id. Film ini menggunakan alur cerita campuran, dengan isi cerita yang menceritakan kehidupan seorang pemuda ketika mengalami depresi.

Awal cerita dimulai dari seorang lakilaki yang mengalami depresi karena tidak mendapatkan inspirasi untuk melanjutkan sebuah lagu yang dibuatnya, tengah cerita atau puncaknya di saat laki-laki tersebut menyerah terhadap keadaan dan kemampuan yang dimilikinya tersebut akhirnya memesan obat penenang. Setelah meminum obat itu ia merasakan lebih bersemangat untuk pertama kalinya dan menuju keluar rumah namun pada saat itu juga tiba-tiba muncul seseorang dengan membawa pisau ditangan kanannya, seolaholah akan membunuh laki-laki tersebut. Sontak, laki-laki yang melihat sosok itu kemudian lari menjauh tanpa melihat arah hingga akhirnya ia merasa lelah dan pusing, dengan keadaan tidak sadar ia terbawa dalam imajinasinya sendiri.

Pada akhir cerita, laki-laki itu berhasil membunuh sosok jubah hitam yang tidak disangka bahwa sosok itu adalah dirinya sendiri dan cerita tiba-tiba kembali pada adegan ketika dirinya akan minum obat penenang. Cerita yang menggunakan alur maju kemudian mundur inilah yang dinamakan alur campuran. Film ini pun juga tidak menggunakan banyak dialog atau film bisu yang hanya fokus pada objek gambar (seorang laki-laki depresi) dan beberapa suara-suara musik pengiring ataupun suara alami yang membuatnya terlihat nampak nyata.

Berdasarkan penjelasan di atas, analisis ini akan melakukan pemaknaan terhadap film pendek "Perspektif Terbalik" melalui setiap komposisi-komposisi yang melekat di dalamnya dengan menggunakan tiga fokus 
penelitian, yaitu interpretasi individu, ekspresi, dan style yang dimaknai secara bersamaan.

\section{Scene 1: berada di dalam kamar Tidur}

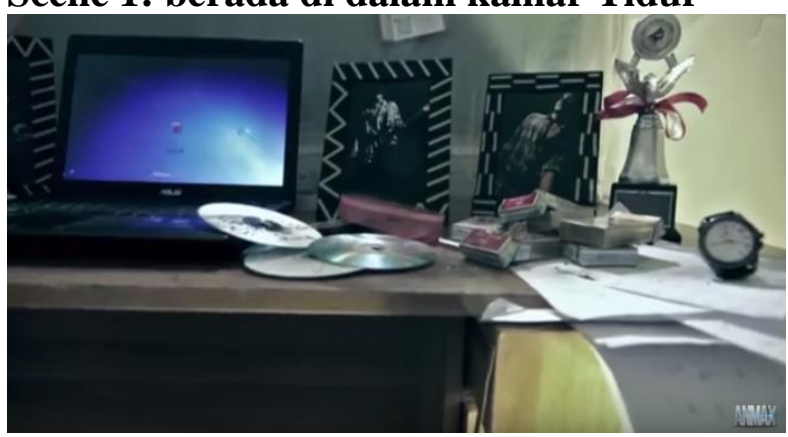

Gambar 1. Adegan dalam Kamar Tidur

Awalnya kamera memperlihatkan meja belajar yang penuh dengan beberapa barang seperti laptop yang sedang menyala, beberapa kepingan kaset $\mathrm{CD}$, kertas, jam tangan, piala, pigora yang di isi dengan foto idola, dan beberapa bungkus rokok yang tidak dibuang. Meja digambarkan dalam keadaan berantakan sehingga memberikan kesan bahwa meja tersebut milik seorang laki-laki yang sedang mengerjakan tugasnya namun ditinggalkan oleh pemiliknya. Penulis menganggap pemilik tersebut adalah laki-laki karena terdapat beberapa bungkus rokok dan foto-foto yang ada di dalam pigora, menunjukkan adanya kesan atau ekspresi yang ingin dikomunikasikan oleh produksi film bahwa pemilik ruangan tersebut adalah seorang laki-laki. Selain itu pengambilan shot ini juga dengan menggunakan bentuk warna yang tidak begitu cerah, menimbulkan kesan yang sedikit suram. Kemudian kamera menuju ke arah pemilik ruangan tersebut dengan sangat cepat, di iringi suara yang mengagetkan agar terlihat semakin suram dan dilanjutkan dengan suara bunyi handphone yang sangat jelas. Hal tersebut dilakukan agar gambar suram dan menakutkan terlihat lebih nyata sehingga penonton dibuat rasa tegang, dalam hal ini penulispun merasakan ketegangan ketika menontonnya.

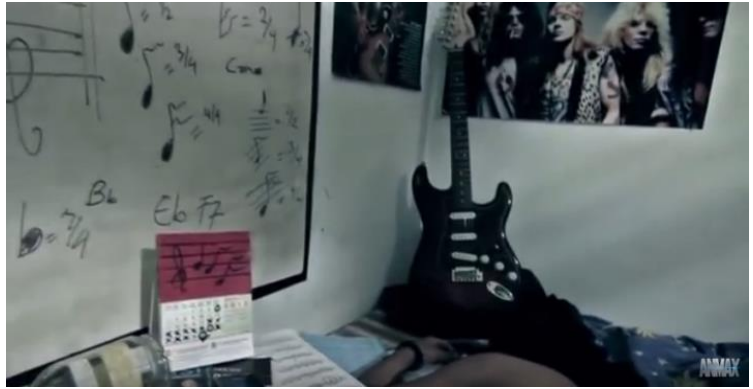

Gambar 2. Adegan dalam Kamar Tidur

Kamera ingin memperlihatkan kondisi sekitar kamar, dimana dinding-dinding kamar terdapat tempelan poster Idola dan papan tulis yang yang berisikan note-note lagu. Selain itu terdapat gitar yang diletakkan di atas kasur yang terletak di pojok kamar, meja belajar yang penuh terdapat botol minuman, kalender yang ditulisi dengan note-note musik, kertaskertas yang bertuliskan note musik, dan handphone yang sedang berdering. Terdapat pula sosok laki-laki tanpa mengenakan baju yang sedang tertidur lelap di atas kasur. Keberadaan barang ataupun posisi-posisi yang telah diatur sedemikian rupa seperti dalam gambar memiliki satu kesatuan, dimana produksi film ingin mengekspresikan dan mengkomunikasikan bahwa pemilik ruangan atau kamar tersebut memang dimiliki oleh seorang laki-laki yang mana kamarnya identik dengan warnawarna gelap, selalu berantakan hampir tidak pernah dirapihkan, dan tidur tanpa mengenakan baju. Selain itu, sosok laki-laki ini juga digambarkan sebagai seorang pemusik yang tidak jauh dari gitar, notenote musik, foto-foto idola dalam pigora dan poster, serta kepingan kaset $\mathrm{CD}$ yang kemungkinan berisi album-album musik. Bentuk warna yang digunakan saat shot adegan ini pun juga menggunakan warna yang tidak cerah agar tetap terlihat suram dan menunjukkan kekhasan kamar laki-laki. 


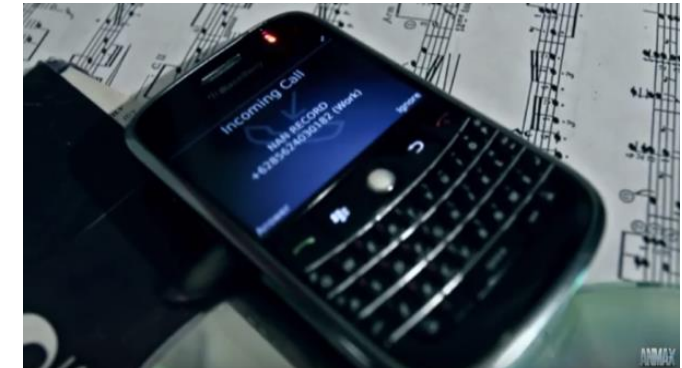

Gambar 3. Adegan dalam Kamar Tidur

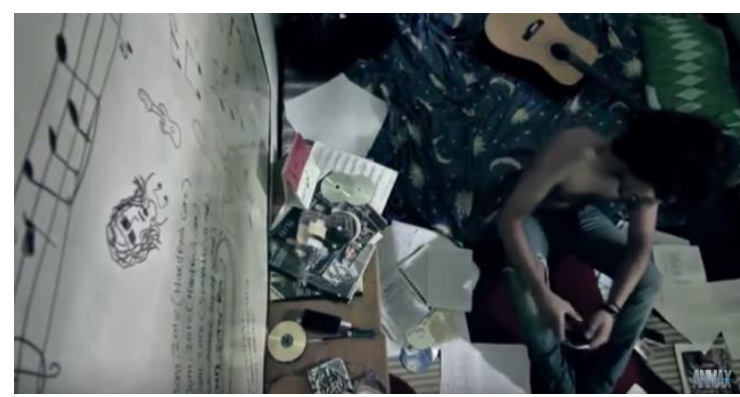

Gambar 4. Adegan dalam Kamar Tidur

Pada gambar tiga, kamera fokus pada handphone yang sedang berdering menunjukkan ada panggilan dari perusahaan rekaman (rekaman musik) yang kemudian dilanjutkan dengan shot empat dalam gambar empat. pada gambar tersebut terlihat laki-laki itu bangun dan kamera mengambil gambar dari atas sehingga nampak secara keseluruhan isi ruangan kamar tersebut. Ternyata, di atas meja juga terdapat beberapa kepingan $\mathrm{CD}$, majalah, dan rokok elektrik vapoor. Selain itu diatas kasur juga terdapat gitar cokelat yang tidur disampingnya. Ruangan sungguh terlihat berantakan, produksi film ingin menegaskan bahwa gambar tersebut merupakan isi ruangan kamar laki-laki yang tidak beraturan atau berantakan melalui bendabenda yang diletakkan dalam isi ruangan tersebut dan terekam oleh kamera.

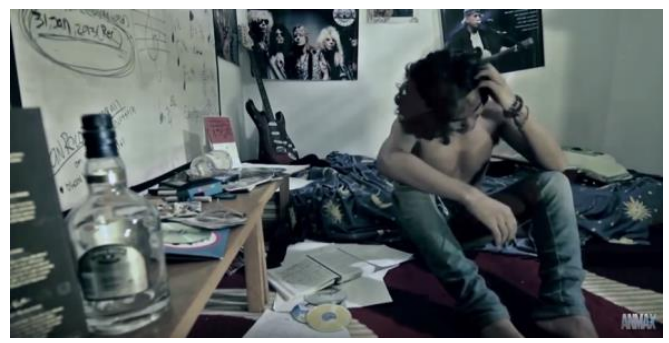

Gambar 5. Adegan dalam kamar Tidur

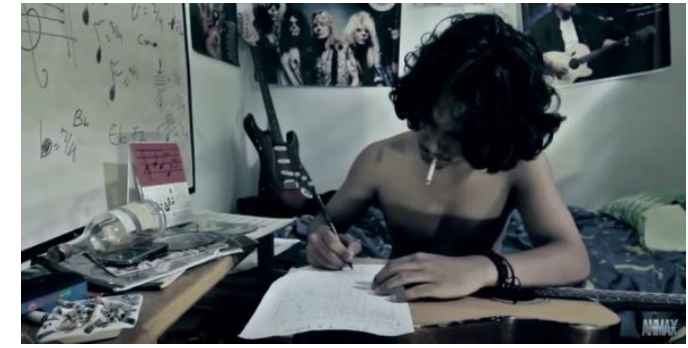

Gambar 6. Adegan berusaha melanjutkan sebuah lagu

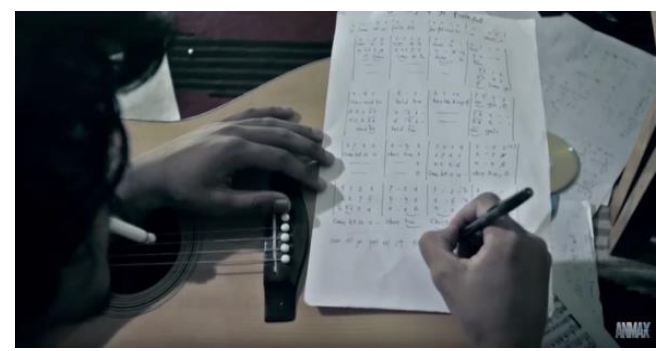

Gambar 7. Adegan berusaha melanjutkan sebuah lagu

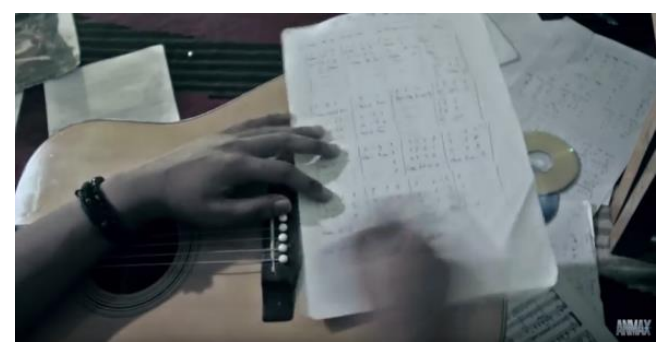

Gambar 8. Adegan Laki-Laki Merasa Depresi

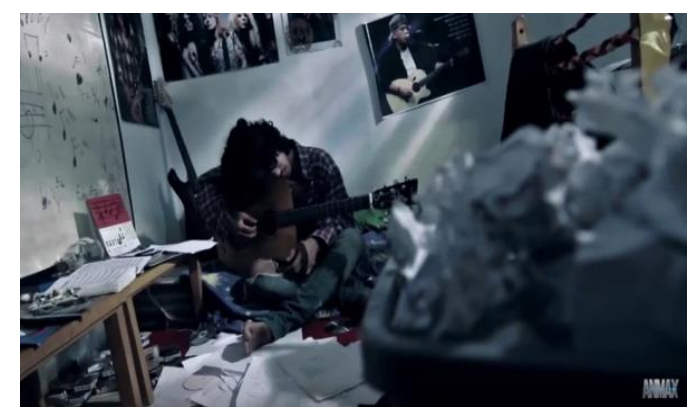

Gambar 9. Adegan Berusaha Melanjutkan

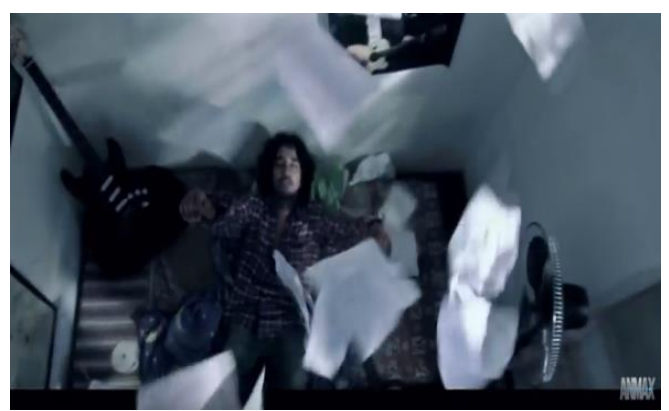

Gambar 10. Adegan Menunjukkan Lelah 
Berdasarkan shot-shot gambar yang ada di atas, menunjukkan bahwa disetiap gambar yang ditampilkan memiliki makna dan maksud tersendiri. Setiap gambar mejelaskan makna secara keutuhan. Gambar lima di atas, produksi film ingin mengekspresikan dan menjelaskan bahwa laki-laki yang akhirnya terbangun akibat bunyi deringan handphone pribadinya itu, membuat dirinya semakin bingung karena perusahaan rekaman telah menelpon. Di dalam adegan sini, penulis dapat menafsirkan bahwa mungkin saja laki-laki ini telah di deadline cepat untuk menyelesaikan satu buah lagu. Kemudian dilanjutkan dengan adegan di gambar enam, tujuh, dan delapan, dimana laki-laki itu berusaha konsentrasi agar mendapatkan inspirasi untuk melanjutkan nada-nada demi keutuhan lagunya namun yang terlihat pada gambar delapan, laki-laki tersebut menunjukkan bahwa dirinya sama sekali tidak mendapatkan inspirasi dengan mencoret-coret kertasnya itu, tapi di adegan berikutnya (gambar 9) ia tetap berusaha kembali untuk menyelesaikan lagu barunya tersebut. Akan tetapi, pada adegan di gambar ke sepuluh laki-laki tersebut telah frustasi dan lelah sehingga melemparkan seluruh kertas-kertas yang berisikan notenote lagu barunya tepat diatas tubuhnya. Hal ini menimbulkan kesan bahwa laki-laki sudah menyerah dengan apa yang telah ia lakukan selama ini.

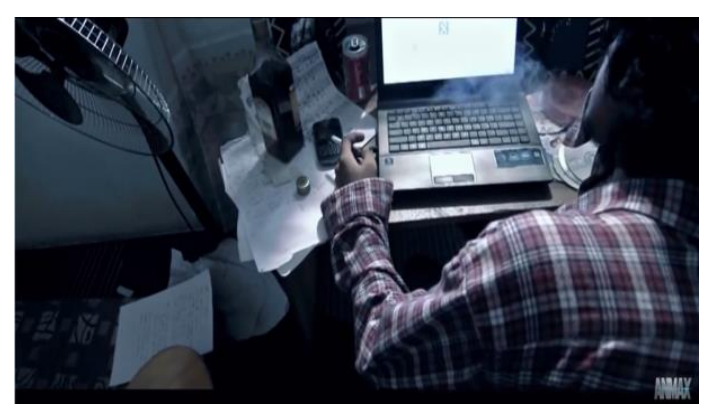

Gambar 11. Adegan Keadaan Bingung

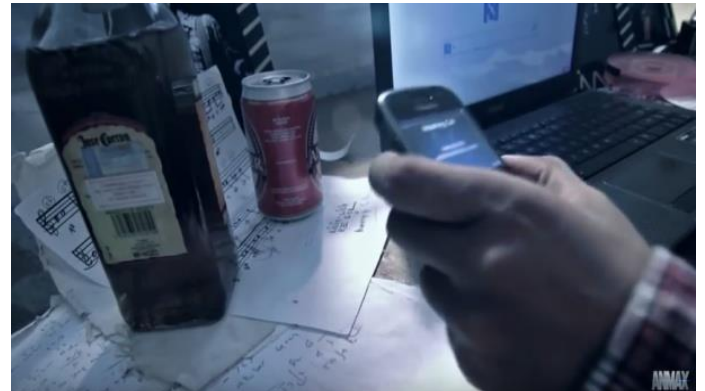

Gambar 12. Adegan Pihak Rekaman Menelpon

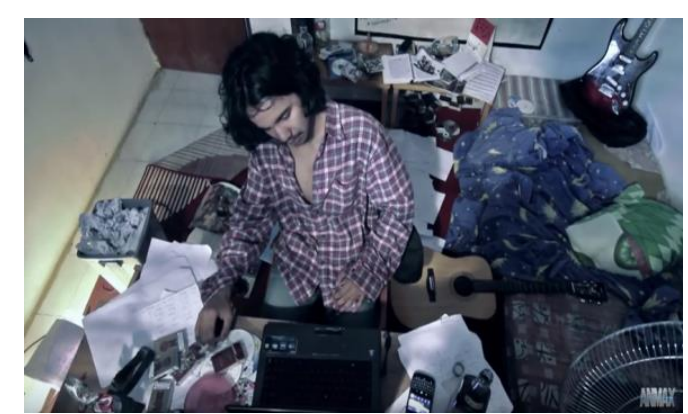

Gambar 13. Adegan Merencanakan Sesuatu

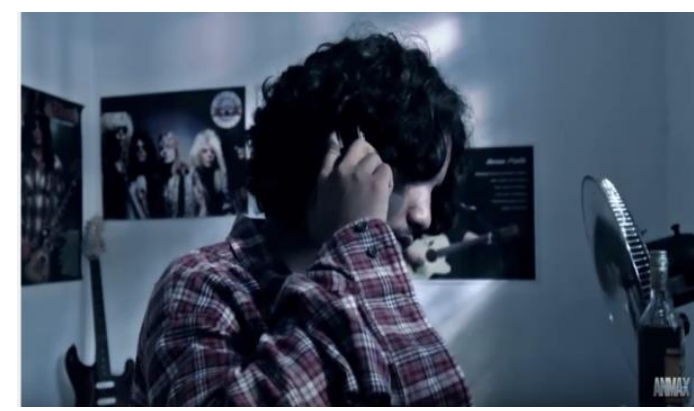

Gambar 14. Adegan Menelpon Seseorang

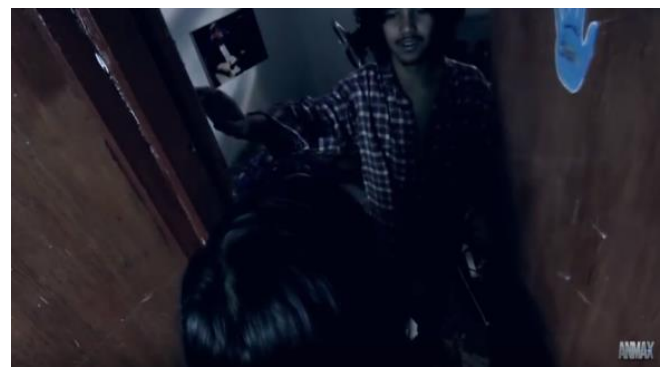

Gambar 15. Bertemu seseorang

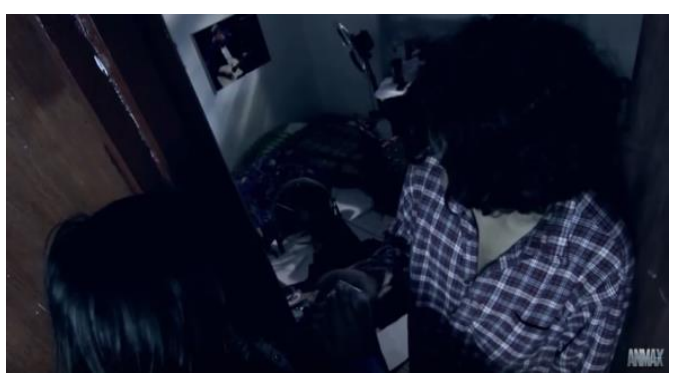

Gambar 16. Adegan Menerima Obat Penenang 
Berdasarkan beberapa shot di atas, produksi film melalui gambar-gambar tersebut ingin menjelaskan kepada penonton mengenai apa yang akan dan ingin dilakukan oleh objek pelaku atau tokoh pemeran utama dalam film tersebut. Seperti pada adegan yang ada di gambar sebelas misalnya, dimana laki-laki diekspresikan dengan keadaan gugup, bingung, dan merencanakan sesuatu. Adegan ini juga diiringi oleh suara bunyi burung yang berada diluar ruangan kamar tidur. Pada adegan ini kemungkinan yang terjadi, produksi film ingin menunjukkan bahwa hari itu matahari sedang menerangi langit meskipun keadaan bentuk warna yang ditunjukkan kepada menonton dengan menggunakan warna gelap, tidak bercahaya terang, dan hanya ada bayangan sinar matahari (pagi-siang) dari luar kamar sehinggu dimasukkan suara burung dari luar.

Pada adegan sebelas, laki-laki tersebut kembali ditelepon oleh perusahaan rekaman yang membuatnya malas untuk mengangkat telepon tersebut karena sudah dipastikan perusahaan itu menagih janji deadline yang seharusnya sudah ditepati. Hal ini membuat laki-laki itu semakin depresi dan di adegan gambar 12, laki-laki tersebut berusaha meyakinkan dirinya untuk melakukan sesuatu hal yang telah direncanakan sebelumnya. Adegan pada gambar 12 akhirnya dibenarkan pada adegan gambar 13, dimana laki-laki itu menelpon seorang temannya dan merencanakan sesuatu. Ternyata di adegan gambar 15 dan 16, lakilaki itu bertemu dengan temannya yang sudah memesan obat penenang di teleponnya tadi untuk menghilangkan rasa depresi yang ia alami selama ini.

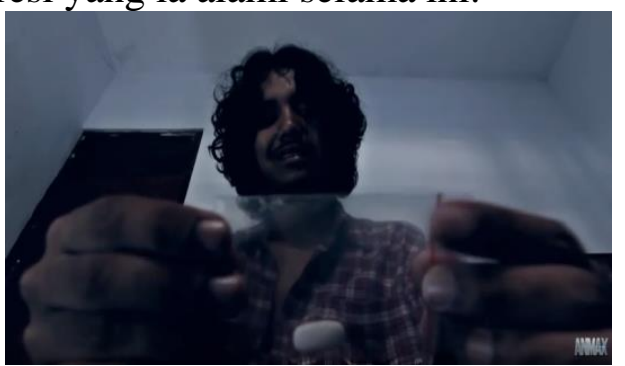

Gambar 17. Adegan Fokus pada Obat Penenang

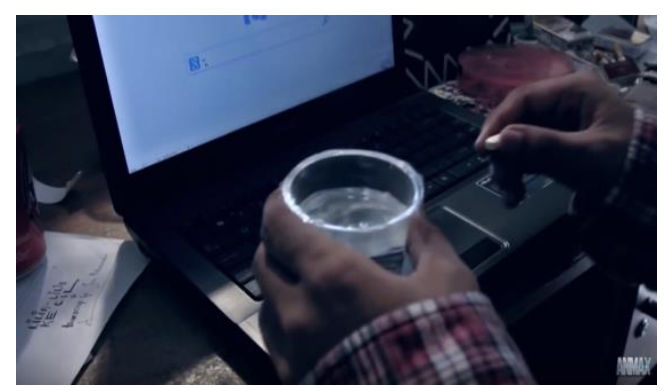

Gambar 18. Adegan pada saat meminum obat

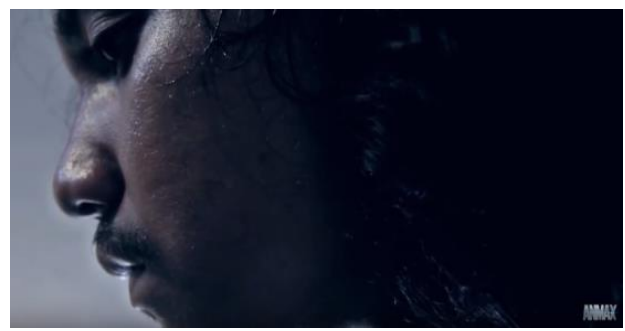

Gambar 19. Adegan fokus peran utama

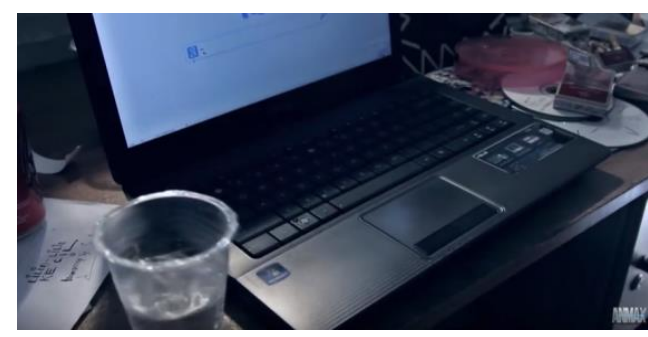

Gambar 20. Adegan air bergerak

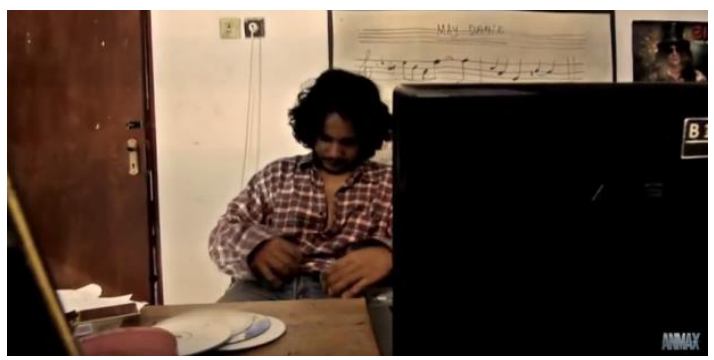

Gambar 21. Adegan setelah meminum obat

Berdasarkan pada beberapa shot di atas, gambar 17 menunjukkan bahwa laki-laki itu telah menerima obat penenang dari salah satu temennya dan ia memutar-mutar obat tersebut seakan-akan berpikir untuk meminumnya atau tidak. Laki-laki itu telah menyiapkan segelas air putih untuk bersiap meminumnya pada gambar 18 , diperkuat dengan gambar 19 dimana laki-laki itu tampak berkeringat, ketakutan, tapi juga membutuhkannya. Ekspresi itu dijiwai oleh laki-laki itu sebagai pemeran utamanya dan juga beberapa perlengkapan yang ada disekitarnya, yang terekam oleh kamera 
sehingga nampak nyata dan mengajak penonton untuk berpikir apa yang akan dilakukannya. Akan tetapi pada adegan yang terdapat di gambar 20, laki-laki itu seolaholeh antara meminum obat itu ataupun tidak, tidak digambarkan secara jelas oleh produksi film namun pemeran utama meletakkan air di dalam gelas yang sudah berkurang. Hal ini agar penonton merasa penasaran dengan apa yang dilakukannya, ditambah dengan bentuk suara musik yang cukup menegangkan. Apabila dimaknai pada adegan tersebut, penulis awalnya sudah mengira bahwa laki-laki itu telah meminum obat tersebut karena berkurangnya air dan kemudian dimunculkan gambar 12, dimana adegan pada gambar itu bentuk warna yang digunakan pada film telah berubah. Warna berubah semakin cerah dan pemeran utama tersenyum bahagia sakan-akan sudah tidak ada masalah yang membebaninya. Adegan tersebut menunjukkan adanya pengaruh dari obat yang telah diminumnya. Bentuk musik yang digunakan untuk mengiringi adegan itupun juga tidak lagi alunan musik yang menegangkan, tetapi alunan musik yang penuh hentakan semangat.

\section{Scene 2: Berada di Luar Rumah (Pinggir jalan)}

Gambar yang terekam dalam film, pada scene kedua ini menunjukan lokasi diluar rumah. Laki-laki itu berjalan keluar rumah seakan-akan hilang dari rasa depresinya dan mencari udara segar atau bersemangat kembali menjalani harinya tersebut.

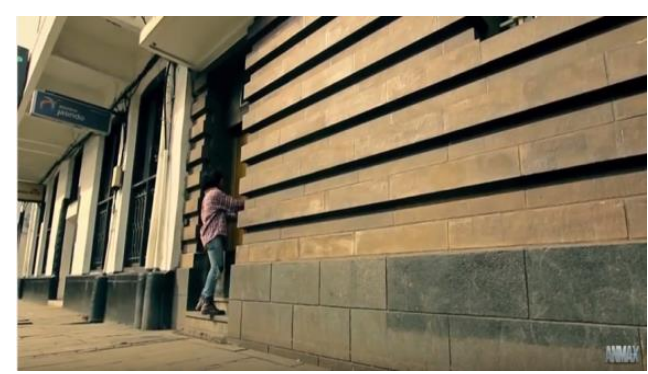

Gambar 22. Adegan berada diluar ruangan

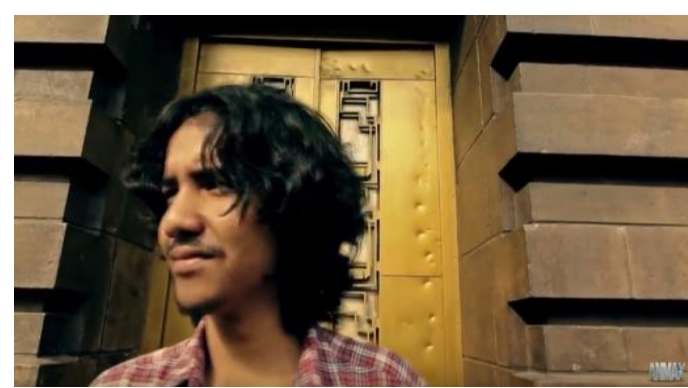

Gambar 23. Adegan senyum bersemangat

Berdasarkan pada kedua gambar shot di atas, laki-laki film telah berada di luar kamar tidurnya. Ia merasakan kenikmatan yang selama ini kemungkinan sudah jarang didapatnya karena sibuknya mengejar deadline hingga merasa depresi. Produksi film ingin menunjukkan bagaimana reaksi tokoh setelah meminum obat penenang yang telah dipesannya. Bentuk warna yang ditampilkan pun juga berbeda dari sebelumsebelumnya, warna yang ditampilkan masih nampak cerah seperti kejadian persis setelah meminum obat tersebut.

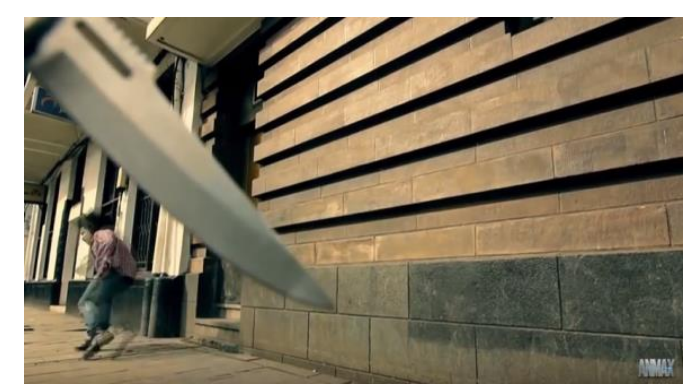

Gambar 24. Adegan seseorang membawa pisau

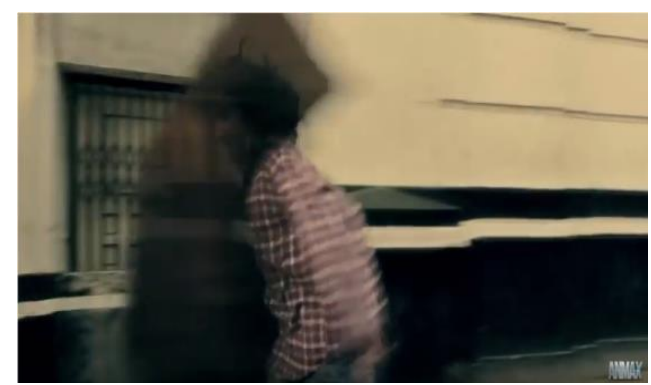

Gambar 25. Adegan sosok jubah hitam lewat

Setelah mendapatkan pencerahan atau pengaruh dari obat tersebut, tiba-tiba lakilaki itu melihat seseorang yang membawa pisau menuju ke arahnya, dengan rasa kaget dan tanpa berpikir panjang laki-laki itu berlari menghindar seseorang yang membawa pisau. Akan tetapi pada gambar 
25, sejauh laki-laki itu menghindar dan berlalu namun bayangin itu akan terus mengikutinya. Gambar-gambar tersebut sudah dapat dengan sendirinya menjelaskan apa maksud dan tujuan yang ingin disampaikan oleh produksi film.

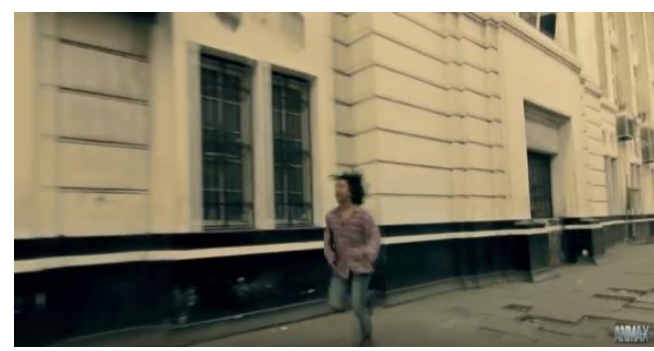

Gambar 26. Adegan berlari

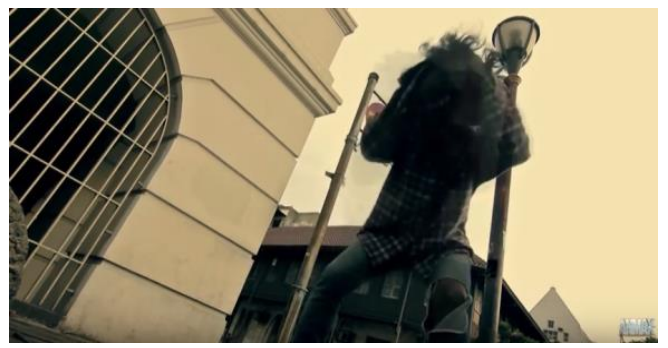

Gambar 27. Adegan mengalami lelah dan pusing

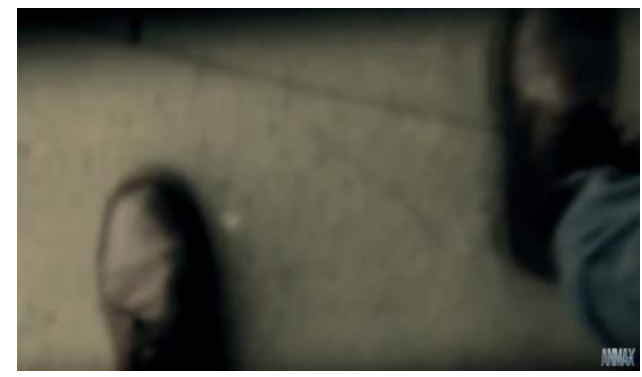

Gambar 28. Adegan pengelihatan yang buram

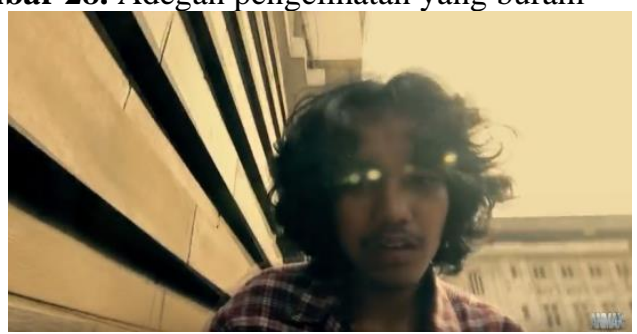

Gambar 29. Adegan pengelihatan yang buram

Pada gambar di atas, menjelaskan bahwa gambar 26 menunjukkan laki-laki itu terus berlari tanpa tau arah yang dituju sampai akhirnya ia merasa lelah dan pusing. Gambar 27 diambil adegannya dari bawah untuk menunjukkan lebih jelas kondisi lakilaki saat itu, yaitu merasa pusing dan ingin membungkuk atau menaruh kepalanya ke arah bawah karena berat (nyeri). Melihat sepatunya saja (gambar 28), matanya sudah buram atau kabur dan di gambar 29, pengambilan dari bawah menunjukkan ekspresi tokoh utama yang pucat dan kelelahan agar tampak lebih jelas dan menjiwai. Bentuk warna yang digunakan di saat-saat mengalami ketegangan pada tokoh utama juga berubah menjadi tidak cerah lagi. Hal ini menunjukkan adanya ketidakjelasan yang terjadi pada tokoh utama, menjelaskan bahwa terjadi sesuatu dengan tokoh tersebut.

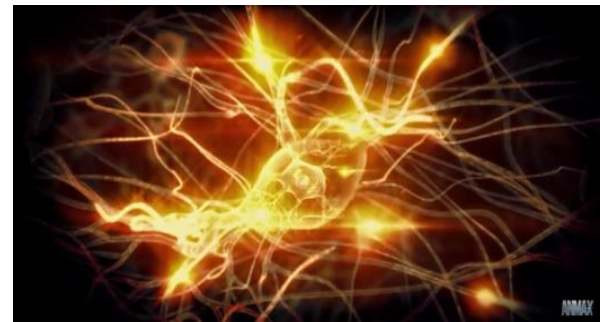

Gambar 30. Adegan pengaruh obat sampai ke otak

Pada gambar di atas, menunjukkan adegan pengaruh dari obat apabila kita sudah meminumnya sampai menyerang ke otak, kita bisa merasakan pusing, senang, sedih, atau pun bahagia. Selain itu pengaruh dari obat penenag itu juga bisa mengakibatkan daya imajinasi kita yang sangat kuat. Seperti yang digambar dalam scene berikut.

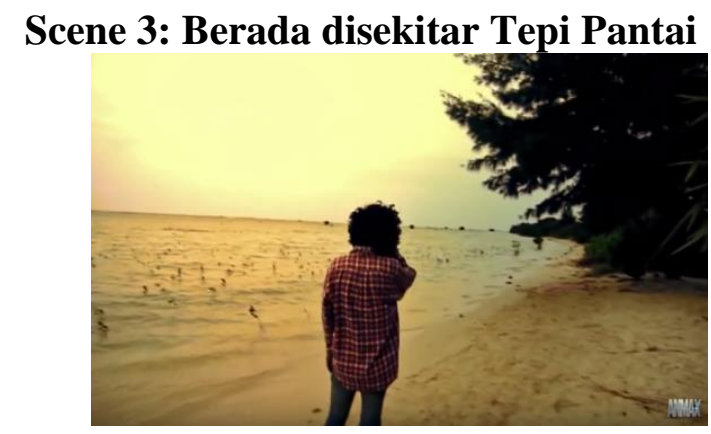

Gambar 31. Adegan tiba-tiba di tepi pantai

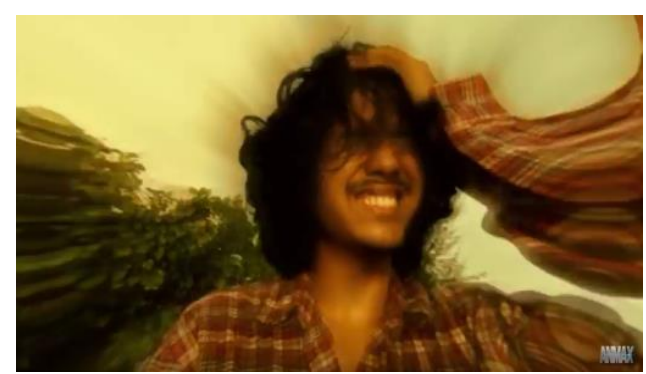

Gambar 32. Adegan merasakan nyeri di kepala 
Kedua gambar di atas, menunjukkan pengaruh obat penenang yang bisa mengakibatkan laki-laki itu berimajinasi tapi seolah-olah nyata di kehidupannya. Dimana pada gambar 31, laki-laki setelah merasakan pusing dan memejamkan matanya, tiba-tiba saat membukanya kembali ia sudah berada di tepi pantai yang sangat tenang dengan di iringi suara air laut yang terseret oleh angin. Dalam gambar tersebut bentuk warna yang ditampilkan oleh produksi film juga menampilkan warna yang tidak cerah, artinya laki-laki itu berada dalam keadaan yang tidak jelas, ia mencoba menyadarkan dirinya mengenai kebenaran realita yang sedang dihadapinya namun setelah memutar-mutar kembali ingatannya (gambar 32) yang ia dapat ialah realita sesungguhnya yang berada di tepi pantai.

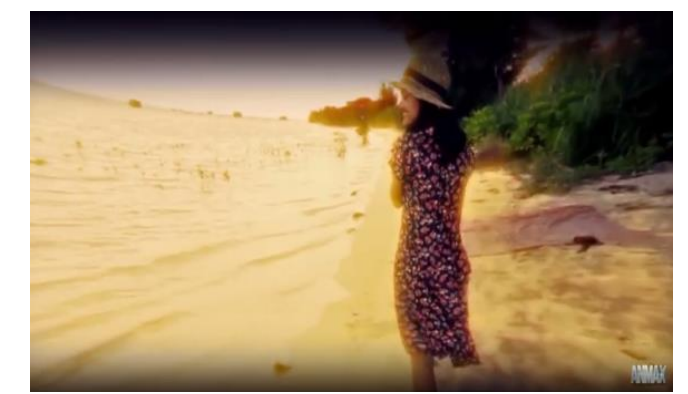

Gambar 33. Adegan melihat seorang perempuan

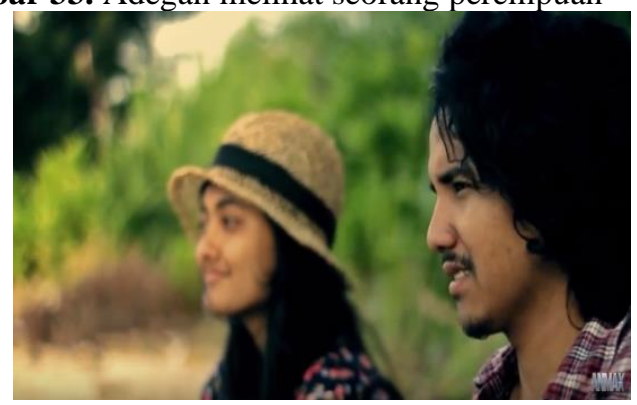

Gambar 34. Adegan mendekati perempuan

Gambar di atas menjelaskan ketika lakilaki itu berada di tepi pantai, dimana pengelihatan laki-laki itu kembali normal. Kejadian ini terlihat dari bentuk warna yang ditampilkan oleh produksi film dengan warna yang cerah sehingga menandakan bahwa laki-laki tersebut dalam keadaan baik-baik saja. Hal ini terjadi tentu saja karena pengaruh dari obat penenang yang ia minum. Secara jelas laki-laki itu melihat seorang perempuan cantik, kemudian menghampirinya dengan rasa senang dan bahagia. Akan tetapi kenikmatan itu hanya sesaat. Pada saat ia tidur disamping perempuan cantik, posisi di atas tikar, tibatiba ia terbangun dan sadar bahwa pantai dan perempuan itu sebagian dari imajinasinya.

\section{Scene 5: Kembali berada di pinggir jalan}

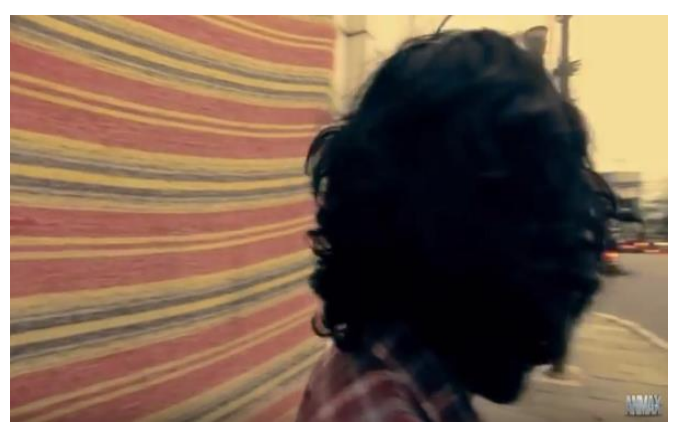

Gambar 35. Adegan kembali di pinggir jalan

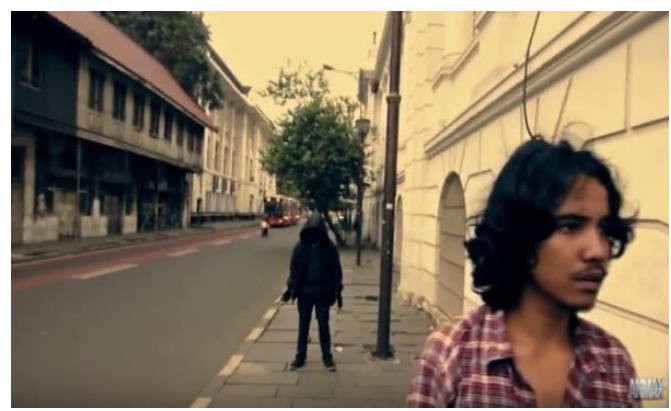

Gambar 36. Adegan sosok jubah hitam muncul

Pada gambar 35, menjelaskan bahwa laki-laki itu kemudian sadar bahwa dirinya masih berada ditepi jalan. Kemungkinan yang terjadi saat ia lelah dan pusing di pinggir jalanan itu, dirinya menyandarkan kepalanya diatas kain yang tertempel pada dinding tersebut dan tidak lain kain itu sama persis dengan karpet yang ada di pantai seperti imajinasinya sehingga dia merasakan kenyaman. Dimana nyaman yang digambarkan dalam imajinasinya bertemu seorang perempuan dan dihadapkan oleh keindahan pantai, sedangkan pada realitanya ia merasa berada di posisi nyaman karena berhasil menyandarkan kepalanya yang saat itu sedang pusing atau sakit. Namun, setelah sadar kehidupan yang tidak jelas kembali terjadi, di gambar 36 pun ia bertemu lagi dengan sosok jubah hitam yang terus 
mengikutinya. Ketidakberesan atau ketidak jelasin yang sedang dialami oleh tokoh utama ini terlihat dari bentuk warna yang digunakan oleh produksi film secara tidak cerah.

\section{Scene 4: Berada di Sebuah Gedung yang Tidak Terpakai}

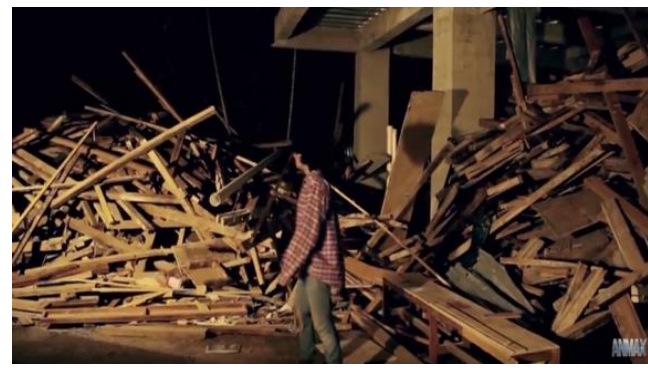

Gambar 38. Adegan di gedung rusak

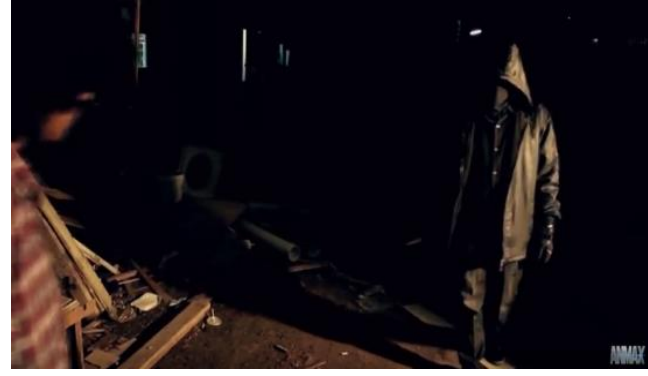

Gambar 37. Adegan sosok jubah hitam muncul

Berdasarkan gambar di atas, menunjukkan bahwa permasalahan yang dialami oleh laki-laki itu belum selesai. Ia berada di posisi yang sangat menyulitkan untuk dirinya. Ia pun juga tidak mengetahui apa yang sedang dirasakannya atau tidak, baik itu sadar atau tidak, semua perasaannya menyampur jadi satu sehingga membuat bingung dengan sebuah keadaan yang dialaminya akan tetapi ia tidak dapat berbuat apa-apa selain larut dalam bayangannya itu. Pada gambar 37, terlihat banyak kayu-kayu rusak yang ditumpuk secara berantakan menyerupai kepingan-kepingan gedung tua yang sudah runtuh dan tidak digunakan lagi, tempat seperti itu dipilih dengan pencahayaan yang redup dan tidak menyeluruh agar film nampak sedikit suram dan menegangkan. Ditambah lagi dengan adegan yang terjadi pada gambar 38, yaitu sosok juba hitam muncul dari arah kegelapan dengan membawa pisau. Penggambaran seperti ini terkesan menyeramkan dan menegangkan bagi penonton, apalagi disertakan dengan suarasuara yang mendebarkan sehingga keadaan suram dapat dirasakan juga oleh penonton.

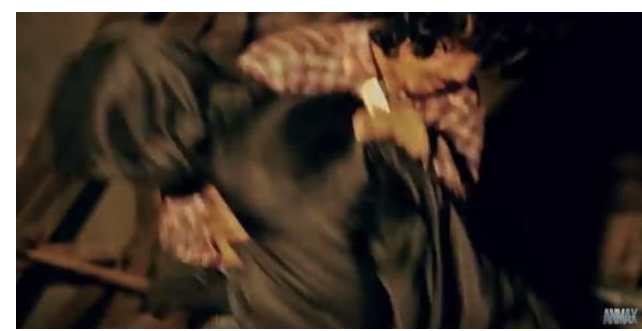

Gambar 39. Adegan terjadinya perkelahian

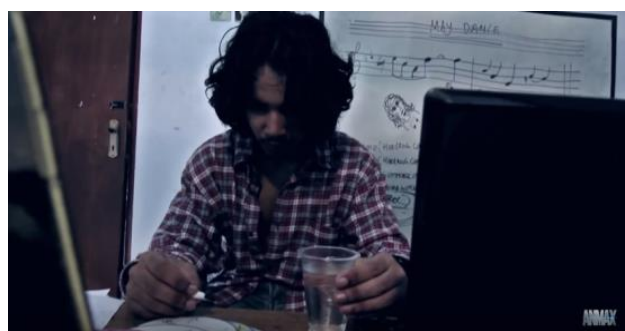

Gambar 40. Adegan belum minum obat

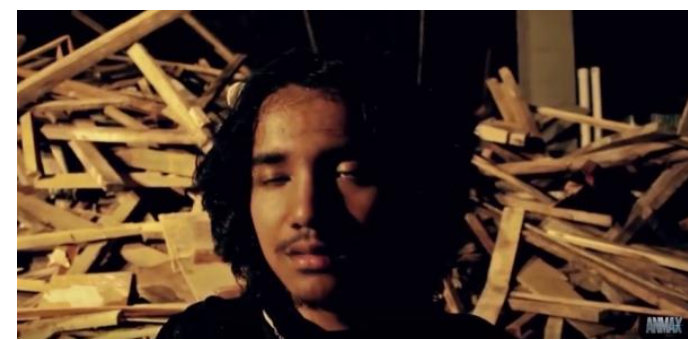

Gambar 41. Sosok laki-laki dibalik jubah hitam

Berdasarkan gambar di atas, setelah perlengkapan yang telah di setting atau diatur sudah cukup jelas, yaitu kondisi yang menegangkan diantara dua orang laki-laki (tokoh utama dan tokoh mengenakan jubah hitam), maka adegan selanjutnya ialah perkelahian. Dimana laki-laki tokoh utama ingin menyelamatkan dirinya dari sosok jubah hitam yang terus-terusan mengikutinya dan beadegan seolah-olah ingin membunuhnya. Ternyata yang terjadi kemudian produksi film mengembalikan alur ketika di dalam kamar, dimana laki-laki itu belum meminum obat penenag yang telah dibelinya seperti pada gambar 40. Dan mengembalikan lagi pada gambar 41, dimana laki-laki itu telah membunuh sosok jubah hitam dengan memberikan beberapa tusukan melalui pisau yang dibawah oleh sosok jubah hitam sendiri. akan tetapi, 
setelah mengetahui siapa dibalik sosok jubah hitam itu sendiri, laki-laki tokoh utama itu terkejut karena sosok itu adalah dirinya sendiri (gambar 42). bentuk warna yang ditampilkan nampak tidak cerah, hal ini menunjukkan bahwa laki-laki itu berada dalam keadaan yang tidak normal. Selain itu, serangkaian yang diceritakan tadi hanya bayangan dirinya sendiri ketika ia benarbenar meminum obat tersebut.

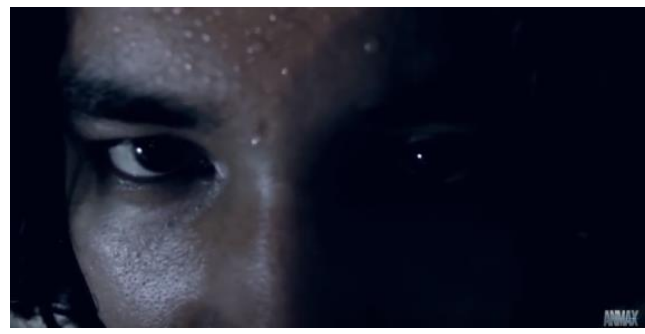

Gambar 40. Adegan di akhir cerita

Pada gambar di atas, produksi film mengambil fokus gambar tokoh utama dibagian tatap matanya, sebagai menunjukkan ekspresi laki-laki itu bahwa menyimpan beberapa makna dari cerita film yang telah diperankan sebelumnya. Baik itu pesan makna dari film dan makna cara berpikir kita ketika melihat film. Pesan yang dapat kita ambil dari film ini adalah ketika dalam keadaan depresi sebaiknya tidak melakukan hal-hal yang negatif, lebih baik memikirkan apa yang akan terjadi setelahnya bila kita menggunakan barangbarang negatif seperti obat penenang tersebut, daripada terjerumus dengan kegiatan negatif sebaiknya kita beristirahat sejenak mencari udara segar beberapa saat untuk mencari inspirasi dan mengembalikan konsentrasi kita terhadap sesuatu yang sedang kita lakukan. Meskipun film ini tidak ada dialog dari tokoh utama, dan tidak ada pemain lainnya namun melalui komposisikomposisi yang melekat di dalam gambar sudah menjelaskan cerita secara keseluruhan sehingga film ini membutuhkan imajinasi kita atau mengajak kita untuk berpikir agar mendapatkan makna yang ingin produksi film sampaikan.

Selain itu, berkaitan dengan judulnya sendiri, yaitu perspektif terbalik maksudnya produksi film ingin mengajak kita agar tidak berpikir secara terstruktur dalam memperspektifkan segala sesuatu, seperti pada film misalnya, kita sudah hanyut dalam alur cerita bahwa laki-laki tersebut menggunakan bat penenang yang kemudian terjadi banyak kekacauan dalam hidupnya dan akhirnya ia meninggal akibat ulahnya sendiri. Ternyata pandangan seperti salah, produksi film memberikan alur mundur dimana tokoh utama belum meminum obat penenang itu. Hal ini produksi film ingin mengajak penonton untuk berpikir sesuatu yang beda dari biasanya.

Berdasarkan penjelasan di atas, penulis memberikan representasi makna melalui tiga fokus penelitian yang telah dijelaskan di awal pendahuluan. Dimana penulis memaknai film melalui interpretasi individu penulis, ekspresi dan komunikasi yang dijelaskan melalui komposisi-komposisi gambar yang melekat di tampilan film, dan bentuk atau gaya film yang dihadirkan oleh produksi film.

\section{KESIMPULAN}

Kesimpulan yang di dapat dari film pendek berjudul "Perspektif Terbalik" adalah film ini termasuk kategori film sebagai karya seni, dimana tidak ada suara dialog didalamnya sehingga mengajak penonton untuk berpikir secara kritis atau berimajinasi sesuai pemahamannya sendiri terkait film ini (melakukan interpretasi).

Hal tersebut sesuai dengan pandangan Rudolf Arnheim yang mengatakan bahwa film sebagai karya seni adalah film yang dapat membuat kita berimajinasi dan tidak meninggalkan unsur seninya, maksudnya selalu fokus pada objek utama film tersebut sehingga tidak meninggalkan unsur artistiknya.

Film ini apabila dilihat berdasarkan analisa terhadap tiga fokus penelitian yang digunakan mengandung makna bahwa film pendek perspektif terbalik disetiap alur, adegan, pencahayaan, setting, serta penataan komposisi-komposisi yang melekat pada gambar memiliki makna secara utuh, dan merupakan satu kesatuan yang tidak dapat dipisahkan karena bila salah satu dari 
mereka ditinggalkan maka film tidak akan bisa dimaknai secara jelas bagaimana alur ceritanya. Seperti misalnya aturan cahaya yang digunakan, dimana cahaya redup ditampilkan yang menunjukkan bahwa tokoh utama dalam keadaan sedang tidak jelas atau random, dan cahaya terang menunjukkan suasana hati atau pun pikiran tokoh utama yang sedang sehat.Selain itu, tata letak komposisi-kompisisi yang melekat pada film seperti suara, pemilihan fokus objek gambar, benda-benda perlengkapan yang disusun secara rapih, dan ditambah editan sinema menjadi pelengkap film ini dapat dimaknai dengan baik karena merekalah yang berbicara sebagai pengganti dialog.

Oleh karena itu film pendek 'perspektif terbalik' salah satu film sebagai karya seni yang sesungguhnya. Film ini juga memiliki pesan bahwa besarnya masalah yang kita hadapi, tidak boleh berujung pada hal-hal yang negatif dan berpikirlah atau menilai segala sesuatunya tidak seperti biasanya (secara terbalik).

\section{REFERENSI}

Arnheim, R. (1957). Film as Art. California: University of California Press.

Arnheim, R. (1969). Visual Thinking.California: University of California Press.

Carroll, N. (1996). Theorizing The Moving Image. New York: Cambridge University Press.

Carroll, N. (2000). Theories of Art Today. Madison: University of Winconsin Press.

Graham, G. (2005). Philosophy of The Arts: An Introduction To Aesthetics. London dan New York: Routledge.

Ida, R. (2014). Metode Penelitian: Studi Media dan Kajian Budaya. Jakarta: Prenada Media Grup.
Rahman, T., \& Ekosiwi, E.K. (2013). "Film Sebagai Seni Visual: Sebuah Refleksi FilosofisTerhadap Ontologi Film Rudolf Arnheim". Program Studi Filsafat, Fakultas Ilmu Pengetahuan Budaya, Universitas Indonesia.

\section{https://www.youtube.com/watch?v=MWQu} Qn8d1S8\&list=RDMWQuQn8d1S8\& index $=1$ Film Pendek berjudul "Perspektif Terbalik". Diakses pada tanggal 26 April 2017, pukul 15.30 Wib.

\section{http://www.kelasfotografi.com/search/label/} Pemula?max-results=8 "Pengertian Cara Pengambilan Gambar Kamera”. Diakses pada tanggal 26 April 2017, pukul 18.30 Wib.

www.filmpendek.id "Keterangan dari film pendek yang berjudul perspektif terbalik". 